\title{
Carcass traits and cutting yields of entire and immunocastrated pigs fed increasing protein levels with and without ractopamine hydrochloride supplementation ${ }^{1-3}$
}

\author{
T. Needham and L. C. Hoffman ${ }^{4}$ \\ University of Stellenbosch, Stellenbosch, South Africa, 7602
}

\begin{abstract}
The objective of this study was to determine the effects of increasing balanced protein, with and without ractopamine hydrochloride (RAC), in the finisher diets of immunocastrates on their carcass cutting yields and respective muscle, fat, and bone proportions. Carcass traits and yields of 120 individually housed entire male pigs and immunocastrates were evaluated following a $2 \times 2 \times 3$ factorial design. Vaccination occurred at 16 and 20 wk of age and slaughtering at $24 \mathrm{wk}$. Up until $20 \mathrm{wk}$ of age, all pigs received a commercial grower diet. Low-, medium-, and high-protein $(7.50,9.79$, and $12.07 \mathrm{~g}$ standardized ileal digestible [SID] lysine $/ \mathrm{kg}$, respectively) diets were then fed for the last $28 \mathrm{~d}$ with RAC supplemented at 0 or $10 \mathrm{mg} / \mathrm{kg}$. Immunocastration and RAC supplementation increased $(P=0.003$ and $P=0.017$, respectively) the live weight at slaughter. The interaction between sex and protein $(P=0.039)$
\end{abstract}

for caliper backfat depths showed greater backfat depths in immunocastrates fed medium protein whereas RAC decreased $(P=0.027)$ the caliper backfat depth. Feeding RAC increased the trotters $(P=$ $0.040)$, tenderloins (fillets; $P<0.001)$, shoulder $(P$ $=0.002)$, hindquarter $(P=0.026)$, loin $(P=0.028)$, and belly $(P=0.044)$ percentages. The shoulder $(P<$ $0.001)$, hindquarter $(P<0.001)$, and loin $(P=0.005)$ muscle percentages were increased and the hindquarter fat percentages were decreased $(P=0.032)$ with RAC supplementation. Immunocastration increased the belly cut $(P=0.006)$, loin fat $(P<0.001)$, and belly fat $(P<0.001)$ percentages. Therefore, carcass cutting and lean yields can be improved by RAC supplementation while decreasing the backfat depth, and the increase in backfat due to immunocastration could be avoided with the correct dietary protein level.

Key words: boar taint, immunocastration, Improvac, pig, protein, ractopamine doi:10.2527/jas2015-9183

\section{INTRODUCTION}

\footnotetext{
${ }^{1}$ Research support provided by the South African Pork Producers' Organisation (SAPPO), the National Research Foundation (NRF), and the South African Research Chair's Initiative. Any opinion, finding, conclusion, or recommendation expressed in this material is that of the author or authors and the National Research Foundation does not accept any liability in this regard.

${ }^{2}$ Assistance with statistical analysis was provided by Prof. Martin Kidd from the Centre for Statistical Consultancy, Stellenbosch.

${ }^{3}$ Products used were provided by Elanco and Zoetis.

${ }^{4}$ Corresponding author: 1ch@sun.ac.za

Received April 9, 2015.

Accepted July 3, 2015.
}

Immunological castration involves vaccinating against $\mathrm{GnRH}$ in order to terminate the production of male steroid hormones. This technique has received increased attention in the pork industry to control boar taint not only in response to the rise in welfare concern and legislation regarding limiting surgical castration but also due to the improved production efficiency it provides when compared with physical castration.

Many carcass classification systems, including South Africa's PORCUS system (Government Gazette, 1992; Table 1), are largely based on subcutaneous fat thickness and, therefore, focus is placed on increasing the lean:fat ratio of the carcass. Therefore, 
Table 1. The South African classification characteristics of pork carcasses (PORCUS) under the Agricultural Product Standards Act 119 of 1990 (Government Gazette, 1992) and calculated using the lean meat percentage ${ }^{1}$ and Hennessy Grading Probe ${ }^{2}$ eye muscle depth $(\mathrm{mm})$ and fat thickness $(\mathrm{mm})$

\begin{tabular}{lcc}
\hline \hline Lean meat, $\%$ & Fat depth, $\mathrm{mm}$ & Class \\
\hline$\geq 70$ & $\leq 12$ & $\mathrm{P}$ \\
$68-69$ & $13-17$ & $\mathrm{O}$ \\
$66-67$ & $18-22$ & $\mathrm{R}$ \\
$64-65$ & $23-27$ & $\mathrm{C}$ \\
$62-63$ & $28-32$ & $\mathrm{U}$ \\
$\leq 61$ & $>32$ & $\mathrm{~S}$ \\
\hline
\end{tabular}

${ }^{1}$ Lean meat $(\%)=72.5114-0.4618 x_{1}+0.0547 x_{2}$, in which $x_{1}=$ fat depth in millimeters and $x_{2}=$ loin muscle depth in millimeters

${ }^{2}$ Hennessy Grading Systems, Auckland, New Zealand.

additives that may allow manipulation of carcass characteristics further than genetics, sex, and nutrition are of interest, such as ractopamine hydrochloride (RAC), which has been shown to increase lean tissue weight (Rikard-Bell et al., 2009). It has been made evident that dietary lysine is important to optimize the carcass characteristics and yields of finisher pigs when fed with and without RAC (Apple et al., 2004a; Webster et al., 2007). Boler et al. (2011) has also shown that immunocastrates (IC) should be fed at a higher lysine level than surgical castrated pigs in order to increase carcass cutting yields and decrease backfat thickness.

Limited studies have been performed on the nutrient responses of IC, especially along with RAC. Also, vaccination schedules, lysine levels, control sex, and carcass fabrication techniques used vary between studies. Therefore, the objective of this study is to determine the effects of increasing balanced protein (lysine) and RAC in finisher diets of IC on carcass cutting yields and their respective muscle, fat, and bone proportions. The hypotheses for this study included 1) that RAC would increase muscle weight while decreasing fat weight and 2) that an increase in balanced protein would allow additional AA to be deposited as lean tissue.

\section{MATERIALS AND METHODS}

All experimental procedures were approved by the Stellenbosch University Research Ethics Committee, Animal Care and Use (SU-ACUM13-00022) and conform to the South African National Standards 10386:2008 (SANS, 2008) in terms of the accepted standards for the use of animals in research and teaching.

\section{Animals, Housing, and Feeding}

One hundred twenty individually penned entire males (E) formed part of a growth performance trial conducted between September and November 2013 at the Agricultural Research Council boar testing facilities (Elsenburg, Western Cape Province, South Africa). They were randomly selected from commercial slaughter stock produced from a Pig Improvement Company (PIC; Pretoria, South Africa) Camborough maternal line (Large White $\times$ Landrace $\times$ White Duroc) and a PIC 410 terminal sire selected for lean growth. The trial was arranged as a $2 \times 2 \times 3$ factorial experiment with the main effects of sex ( $\mathrm{C}$ versus $\mathrm{E})$, RAC ( 0 or $10 \mathrm{mg} / \mathrm{kg}$ ), and balanced protein level (low, medium, and high) shown in Table 2.

The pigs were randomly placed at 13 wk of age to allow for acclimatization in terms of environment and weighing procedures. Until $20 \mathrm{wk}$ of age, the pigs received a commercial grower feed (12.3 MJ/kg DE, 160 $\mathrm{g} / \mathrm{kg} \mathrm{CP}$, and $8.5 \mathrm{~g}$ standardized ileal digestible(SID) lysine $/ \mathrm{kg}$ ) ad libitum in the pelleted form consisting of maize as the primary energy source and soybean meal as the primary protein source. The PIC Nutrients Specification Manual (PIC, 2011) was consulted to determine the SID lysine percentages for the experimental diets. According to the manufacturer's feeding directions for Paylean (Elanco, Indianapolis, IN), the diet must contain at least $160 \mathrm{~g} \mathrm{CP} / \mathrm{kg}$ and, therefore, this value was used when formulating the low-protein diet. Fresh water was freely available from a nipple drinker in each pen. The pens were divided into a concrete sleeping area covered in clean pine wood shavings and a slanted dunging area free from shavings.

From 16 wk of age, each pig was weighed, feed intake was recorded, and backfat was measured $65 \mathrm{~mm}$ from the dorsal midline using a Renco Lean-Meater digital backfat indicator (Renco, Minneapolis, MN) at the last rib counted from the cranial end. The pigs randomly allocated for immunocastration were vaccinated at 16 and 20 wk of age using an Improvac safety vaccination gun at a dose of $2 \mathrm{~mL}$ of Improvac (Zoetis, Sandton, South Africa) behind and below the base of the ear. Vaccinations were thus 4 wk apart and the booster was given 4 wk before slaughter. At 20 wk of age, the diets were changed to those of varying protein content (7.50, 9.79 and $12.07 \mathrm{~g}$ digestible lysine/kg; Table 2). Paylean (RAC) was given continuously as part of the complete diet for the last $28 \mathrm{~d}$ of growth at $10 \mathrm{mg} / \mathrm{kg}$ to the respective allocated treatments and a zero day withdrawal was used. 
Table 2. Ingredient and nutrient composition of the low and high balanced dietary protein experimental finisher diets fed to the pigs from 20 to 24 wk of age; all values are on an as-is basis and all AA values shown are digestible values

\begin{tabular}{|c|c|c|c|}
\hline \multirow[b]{2}{*}{ Ingredient composition, $\mathrm{g} / \mathrm{kg}$} & \multicolumn{3}{|c|}{ Diet } \\
\hline & Low & Medium & High \\
\hline Maize & 326.77 & 266.22 & 205.67 \\
\hline Wheat bran & 294.67 & 209.50 & 124.33 \\
\hline Barley meal & 150 & 150 & 150 \\
\hline Soya oil cake ( $470 \mathrm{~g} \mathrm{CP} / \mathrm{kg})$ & 126.67 & 213.42 & 300.17 \\
\hline Sunflower oil cake ( $360 \mathrm{~g} \mathrm{CP} / \mathrm{kg}$ ) & 50 & 100 & 150 \\
\hline Canola oil & 25.0 & 27.5 & 30 \\
\hline Limestone & 14.17 & 13.42 & 12.67 \\
\hline Salt & 4.3 & 4.36 & 4.42 \\
\hline L-Lysine HCL & 2 & 1.9 & 1.8 \\
\hline Vitamin and mineral premix ${ }^{1}$ & 2 & 2 & 2 \\
\hline Monocalcium phosphate & 1.9 & 1.0 & 0 \\
\hline Mycotoxin binder & 1 & 1 & 1 \\
\hline L-Threonine & 0.53 & 0.36 & 0.18 \\
\hline Phytase enzyme & 0.5 & 0.5 & 0.5 \\
\hline DL-Methionine & 0.27 & 0.32 & 0.37 \\
\hline Choline chloride liquid & 0.13 & 0.13 & 0.13 \\
\hline $\begin{array}{l}\text { Xylanase and } \beta \text {-glucanase enzyme } \\
\text { combination }\end{array}$ & 0.1 & 0.1 & 0.1 \\
\hline Maize gluten meal (600 g CP/kg) & 0 & 8.34 & 16.67 \\
\hline \multicolumn{4}{|l|}{ Calculated nutrient composition } \\
\hline NE pig, MJ/kg & 9.2 & 9.2 & 9.2 \\
\hline DE pig, MJ/kg & 13.29 & 13.56 & 13.83 \\
\hline $\mathrm{CP}, \mathrm{g} / \mathrm{kg}$ & 161.16 & 208.48 & 255.8 \\
\hline Crude starch, g/kg & 359.2 & 315.1 & 271.02 \\
\hline Crude fiber, $\mathrm{g} / \mathrm{kg}$ & 60.76 & 64.42 & 68.07 \\
\hline Crude fat, $\mathrm{g} / \mathrm{kg}$ & 49.12 & 48.26 & 47.4 \\
\hline Ash, g/kg & 59.31 & 65.17 & 71.02 \\
\hline \multicolumn{4}{|l|}{$\mathrm{AA}, \mathrm{g} / \mathrm{kg}$} \\
\hline Lysine & 7.50 & 9.79 & 12.07 \\
\hline Methionine & 2.47 & 3.28 & 4.09 \\
\hline TSAA $^{2}$ & 4.74 & 6.11 & 7.48 \\
\hline Tryptophan & 1.59 & 2.12 & 2.66 \\
\hline Threonine & 4.88 & 6.36 & 7.85 \\
\hline Arginine & 9.24 & 12.68 & 16.12 \\
\hline Isoleucine & 5.08 & 7.09 & 9.09 \\
\hline Leucine & 10.33 & 13.78 & 17.24 \\
\hline Valine & 6.11 & 8.12 & 10.12 \\
\hline Histidine & 3.48 & 4.55 & 5.61 \\
\hline Calcium, $\mathrm{g} / \mathrm{kg}$ & 7.51 & 7.5 & 7.49 \\
\hline Total phosphorus, $\mathrm{g} / \mathrm{kg}$ & 6.86 & 7.14 & 7.42 \\
\hline Available phosphorus, $g / k g$ & 2.5 & 2.52 & 2.53 \\
\hline Sodium, $\mathrm{g} / \mathrm{kg}$ & 2.00 & 2.00 & 2.00 \\
\hline Potassium, $\mathrm{g} / \mathrm{kg}$ & 9.86 & 11.40 & 12.94 \\
\hline
\end{tabular}

${ }^{1}$ Vitamin and mineral premix: 5,489.5 IU/kg vitamin A, 1,005.3 IU/kg vitamin $\mathrm{D}, 27.6 \mathrm{IU} / \mathrm{kg}$ vitamin $\mathrm{E}, 2.8 \mathrm{mg} / \mathrm{kg}$ vitamin $\mathrm{K}, 22.0 \mathrm{mg} / \mathrm{kg}$ niacin, $4.9 \mathrm{mg} / \mathrm{kg}$ riboflavin, $16.5 \mathrm{mg} / \mathrm{kg}$ D-pantothenate, $22.0 \mu \mathrm{g} / \mathrm{kg}$ vitamin $\mathrm{B}_{12}, 100 \mathrm{mg} / \mathrm{kg}$ zinc, $66 \mathrm{mg} / \mathrm{kg}$ iron, $25 \mathrm{mg} / \mathrm{kg}$ manganese, $10 \mathrm{mg} / \mathrm{kg}$ copper, $0.33 \mathrm{mg} / \mathrm{kg}$ iodine, and $0.25 \mathrm{mg} / \mathrm{kg}$ selenium. This is an approximate premix composition obtained for grow-finish Pig Improvement Company (PIC, Pretoria, South Africa) pigs from $68 \mathrm{~kg}$ live weight to slaughter from the PIC Nutrients Specification Manual (PIC, 2011). These are suggested specifications for the amount of vitamins/minerals per kilogram of a complete diet.

${ }^{2} \mathrm{TSSA}=$ total sulfur-containing AA.

\section{Slaughter}

At 24 wk of age, all pigs were slaughtered at a commercial abattoir in the Western Cape Province, South Africa, 45 min away from the facilities at Elsenburg. Each pig was individually loaded and a stocking density of $0.3 \mathrm{~m}^{2}$ per pig was used during transport to minimize the potential for injuries. Pigs were electrically stunned with electrodes at the base of each ear and exsanguinated using a thoracic stick. Each carcass was weighed to determine the HCW and the Hennessy Grading Probe (HGP; Hennessy Grading Systems, Auckland, New Zealand) was used to determine the backfat thickness and loin muscle thickness between the second and third last rib from the cranial end and $45 \mathrm{~mm}$ from the dorsal midline. Lean meat percentage was estimated using the following prediction equation: $y=72.5114-0.4618 x_{1}+0.0547 x_{2}$, in which $x_{1}=$ fat depth in millimeters and $x_{2}=$ loin muscle depth in millimeters. The pigs entered a cold room at $4{ }^{\circ} \mathrm{C}$ for $24 \mathrm{~h}$ whilst being hung by both Achilles tendons.

\section{Carcass Sectioning and Deboning}

After approximately $24 \mathrm{~h}$, the carcasses were deboned by trained and experienced staff at the abattoir using commercial techniques described by Hoffman (1987) and Pieterse (2006). Each carcass was also given a carcass lesion score as described by McCauley et al. (2001) and used by Lealiifano et al. (2011): 0 = unmarked, $1=$ minimal bruising/scratching, 2 = obvious bruising/ scratching, and $3=$ severe bruising (entire carcass).

The head of each carcass was removed by cutting at the atlanto-occipital joint at a $90^{\circ}$ angle to the ventral line and weighed. The 2 psoas major muscles were removed and weighed together for each pig. The carcass was then placed on a band saw and sectioned into the shoulder, belly, loin, hindquarter, shanks, and trotters. Firstly, the trotters were removed at the carpal for the fore legs and above the hock, or the tarsal joint, for the hind legs. The hind leg shank was then removed by cutting below the knee joint where the femur meets the tibia, passing through approximately the midpoint of the tibia and fibula in the hind legs. The fore leg shank was removed by cutting above the elbow joint where the humerus meets the radius and ulna. The shoulder was removed by cutting directly behind the fore leg in the region of the third and fourth rib from the cranial end. The hindquarter was sectioned off by cutting within the sacral vertebrae region by passing through the narrow part of the hip bone also known as the shaft of the ilium. The belly was then sectioned from the loin by cutting a straight line just below, or ventrally to, the vertebra and the psoas 
major and psoas minor muscles (tenderloin) position towards the hindquarters.

The right-hand side loins of 96 pigs were sampled by selecting 8 of the midweight pigs from each treatment in terms of their live weight at slaughter. Each loin was taken from the right-hand side of the carcass and cut at between the second and third last rib. The cranial section of each untrimmed loin (bone-in, rindon) was wrapped in individual water impermeable plastic bags, placed in cardboard boxes, and taken back under insulated conditions to Stellenbosch University (Stellenbosch, South Africa) for analyses. These loins were used for meat quality and chemical analysis (Needham and Hoffman, 2015). The fat thickness and skin thickness of each of these 96 loins were measured using an engineering caliper at the same position as the HGP backfat thickness measurement.

The left-hand side shoulder, belly, loin, hindquarter, shanks (fore and hind together), and trotters (fore and hind together) were weighed. The shoulder, belly, loin, and hindquarter were then deboned and trimmed into muscle and subcutaneous fat (with skin) by hand using commercial abattoir techniques. The skin and subcutaneous fat were removed by cutting as close as possible to the muscle of each cut. All bones and cartilage were removed from the cuts and any hard connective tissues were trimmed. However, the intercostal muscles of the ribs were left on the bone. For each cut, the muscle, bone, and fat (with skin) were weighed and expressed either as a percentage of the dressed HCW or the dressed side HCW. The dressed HCW included the head, trotters, and tenderloins.

\section{Statistical Analysis}

Statistical analysis was performed using STATISTICA 64 version 11 (StatSoft Southern Africa, Sandton, South Africa) with the main effects tested being sex, RAC, and protein level as well as their interactions. The data was tested for normality of the residuals and homogeneity using Levene's test. Univariate ANOVA were then performed using the GLM procedure and followed by Fisher's LSD comparison of least squares means. Significant interactions, effects, and differences were reported at a significance level of 5\%. Data values are reported as least squares means \pm SEM. The cuts were examined as a percentage of the hot carcass side weight (including trotters, shanks, shoulder, hindquarter, belly, and loin) or whole carcass weight (including tenderloins and head) so that the carcass weight of the pigs could be included for a better representation of differences in the carcass yields.

\section{RESULTS}

The results for the carcass traits are shown in Table 3 and carcass yields in Tables 4 and 5. Unless stated otherwise, there were no interactions between the main effects and the latter are, therefore, discussed.

\section{Live Weight, HCW, Carcass Scores, and Fat Depth}

The live weight at slaughter was influenced by the main effects of sex and RAC such that IC were approximately $5 \mathrm{~kg}$ heavier $(P=0.003)$ than $\mathrm{E}$ and RAC-fed pigs were approximately $4 \mathrm{~kg}$ heavier $(P=$ 0.017 ) than non-RAC-fed pigs (Table 3 ). However, there were no significant differences for the dressed $\mathrm{HCW}$ between the treatments. There were also no significant differences for HGP fat depth measured in the abattoir. However, the caliper fat thickness showed a sex and protein interaction $(P=0.039)$. The IC carcasses fed the medium protein diet had greater caliper backfat depths than $\mathrm{E}$ on all protein levels $(P=0.021$, $P=0.010$, and $P=0.001$ for E fed the low, medium and high protein diets, respectively) as well as IC fed the low protein $\operatorname{diet}(P=0.003 ;$ Fig. 1$)$. Also, E fed the high protein diet had decreased $(P=0.030)$ backfat depths compared with IC fed the high protein diet and the inclusion of RAC decreased $(P=0.027)$ backfat depths. There was no effect of sex, RAC, or protein level on the caliper skin thickness. Due to the lack of effect on the HCW and HGP fat thickness, there were no differences seen in the lean meat percentage between treatments.

The average $\mathrm{HCW}$ was approximately $101 \mathrm{~kg}$ (Table 3) and, therefore, there were differences in carcass classification with most of the pigs being classified as "Sausage pigs," (Government Gazette, 1992) as any carcass over $100 \mathrm{~kg}$ is immediately classified as a "Sausage pig" regardless of fat depth or lean meat percentage. However, the average HGP fat thickness was approximately 17 to $18 \mathrm{~mm}$ and, therefore, the carcasses could have been classified under the PORCUS system (Table 1) as either "O" (68 to 69\% lean meat; Table 1) or "R" (66 to 67\% lean meat; Table 1) if they had been lighter. There were also no differences between the various factors for the carcass conformation score (visual appraisal according to South African classification system; Government Gazette, 1992) with an average score of 4 (round carcass) across the treatments. The carcass lesion score data showed no significant differences between the sexes, with an average score of 2 for both E and IC. 
Table 3. The effects of sex, ractopamine, and protein level on the live weight (kg), hot dressed carcass weight (kg), Hennessy Grading Probe ${ }^{1}$ (HGP) fat depth (mm), caliper fat depth (mm), caliper skin depth (mm), and lean meat percentage as estimated using the HGP of pork carcasses (least squares means \pm SEM)

\begin{tabular}{|c|c|c|c|c|c|c|}
\hline Effect & Live weight, $\mathrm{kg}$ & $\mathrm{HCW}, \mathrm{kg}$ & $\begin{array}{c}\text { HGP fat } \\
\text { depth, mm }\end{array}$ & Lean meat, \% & $\begin{array}{l}\text { Caliper fat } \\
\text { depth, mm }\end{array}$ & $\begin{array}{c}\text { Caliper skin } \\
\text { depth, mm }\end{array}$ \\
\hline \multicolumn{7}{|l|}{$\overline{\mathrm{Sex}^{2}}$} \\
\hline E & $125.5^{\mathrm{b}} \pm 1.34$ & $101.4 \pm 0.89$ & $17.4 \pm 0.40$ & $67.5 \pm 0.16$ & $9.2 \pm 0.31$ & $3.8 \pm 0.14$ \\
\hline IC & $130.7^{\mathrm{a}} \pm 1.20$ & $101.8 \pm 1.14$ & $17.2 \pm 0.37$ & $67.5 \pm 0.15$ & $10.4 \pm 0.38$ & $3.6 \pm 0.22$ \\
\hline \multicolumn{7}{|l|}{$\mathrm{RAC}^{3}$} \\
\hline $0 \mathrm{mg} / \mathrm{kg}$ & $126.0^{\mathrm{b}} \pm 1.02$ & $101.95 \pm 0.96$ & $17.4 \pm 0.37$ & $67.4 \pm 0.15$ & $10.3^{\mathrm{a}} \pm 0.34$ & $3.6 \pm 0.22$ \\
\hline $10 \mathrm{mg} / \mathrm{kg}$ & $130.3^{\mathrm{a}} \pm 1.51$ & $101.31 \pm 1.09$ & $17.1 \pm 0.40$ & $67.6 \pm 0.16$ & $9.3^{b} \pm 0.36$ & $3.9 \pm 0.14$ \\
\hline \multicolumn{7}{|l|}{ Protein $^{4}$} \\
\hline Low & $127.5 \pm 1.80$ & $101.3 \pm 0.87$ & $17.0 \pm 0.43$ & $67.6 \pm 0.17$ & $9.3 \pm 0.43$ & $3.7 \pm 0.25$ \\
\hline Medium & $128.0 \pm 1.54$ & $102.3 \pm 1.48$ & $17.7 \pm 0.53$ & $67.3 \pm 0.21$ & $10.4 \pm 0.49$ & $3.8 \pm 0.26$ \\
\hline High & $129.0 \pm 1.51$ & $101.3 \pm 1.35$ & $17.1 \pm 0.45$ & $67.6 \pm 0.18$ & $9.6 \pm 0.38$ & $3.7 \pm 0.17$ \\
\hline \multicolumn{7}{|l|}{ Sex $\times$ protein } \\
\hline E Low & & & & & $9.6^{\mathrm{cb}} \pm 0.66$ & \\
\hline E Medium & & & & & $9.4^{\mathrm{cb}} \pm 0.44$ & \\
\hline E High & & & & & $8.7^{\mathrm{c}} \pm 0.52$ & \\
\hline IC Low & & & & & $9.0^{\mathrm{cb}} \pm 0.55$ & \\
\hline IC Medium & & & & & $11.5^{\mathrm{a}} \pm 0.79$ & \\
\hline IC High & & & & & $10.5^{\mathrm{ab}} \pm 0.47$ & \\
\hline
\end{tabular}

${ }^{\mathrm{a}-\mathrm{c}}$ Least squares means within columns for the main effects and interactions with different superscripts are significantly different $(P<0.05)$.

${ }^{1}$ Hennessy Grading Systems, Auckland, New Zealand.

${ }^{2} \mathrm{E}=$ entire males; $\mathrm{IC}=$ immunocastrates.

${ }^{3} \mathrm{RAC}=$ ractopamine hydrochloride (Paylean; Elanco, Indianapolis, IN).

${ }^{4} \mathrm{Low}=$ fed low protein diet (7.50 g standard ileal digestible lysine $/ \mathrm{kg}$; Medium = fed medium protein diet $(9.75 \mathrm{~g}$ standard ileal digestible lysine $/ \mathrm{kg})$; High $=$ fed high protein diet (12.07 $\mathrm{g}$ standard ileal digestible lysine $/ \mathrm{kg})$

Table 4. The effects of sex, ractopamine, and protein level on the head, trotters, shanks, and tenderloins expressed as a percentage of the carcass weight (head and tenderloins) and half carcass weight (trotters and shanks) of pork carcasses (least squares means \pm SEM)

\begin{tabular}{lcccc}
\hline \hline Effect & Head, $\%$ & Trotters, $\%$ & Shanks, $\%$ & Tenderloins, $\%$ \\
\hline Sex $^{1}$ & & & & \\
E & $8.34 \pm 0.11$ & $2.76 \pm 0.05$ & $4.48 \pm 0.07$ & $0.49 \pm 0.01$ \\
IC & $8.38 \pm 0.14$ & $2.65 \pm 0.04$ & $4.88 \pm 0.09$ & $0.51 \pm 0.01$ \\
RAC $^{2}$ & & & & \\
$0 \mathrm{mg} / \mathrm{kg}$ & $8.27 \pm 0.11$ & $2.77^{\mathrm{a}} \pm 0.04$ & $4.78 \pm 0.08$ & $0.46^{\mathrm{b}} \pm 0.009$ \\
$10 \mathrm{mg} / \mathrm{kg}$ & $8.45 \pm 0.13$ & $2.64^{\mathrm{b}} \pm 0.04$ & $4.87 \pm 0.07$ & $0.54^{\mathrm{a}} \pm 0.012$ \\
Protein & & & & \\
Low & $8.41 \pm 0.12$ & $2.70 \pm 0.04$ & $4.87 \pm 0.07$ & $0.48 \pm 0.01$ \\
Medium & $8.29 \pm 0.16$ & $2.68 \pm 0.05$ & $4.80 \pm 0.12$ & $0.50 \pm 0.01$ \\
High & $8.38 \pm 0.17$ & $2.73 \pm 0.06$ & $4.84 \pm 0.09$ & $0.51 \pm 0.02$ \\
\hline
\end{tabular}

${ }^{\mathrm{a}-\mathrm{c}}$ Least squares means within columns for the main effects and interactions with different superscripts are significantly different $(P<0.05)$.

${ }^{1} \mathrm{E}=$ entire males; $\mathrm{IC}=$ immunocastrates.

${ }^{2} \mathrm{RAC}=$ ractopamine hydrochloride (Paylean; Elanco, Indianapolis, IN).

${ }^{3}$ Low $=$ fed low protein diet $(7.50 \mathrm{~g}$ standard ileal digestible lysine/ $\mathrm{kg} ;$ Medium $=$ fed medium protein diet $(9.75 \mathrm{~g}$ standard ileal digestible lysine $/ \mathrm{kg}$ ); High = fed high protein diet (12.07 g standard ileal digestible lysine $/ \mathrm{kg}$ )

\section{Carcass Cutting Yields}

There were no significant differences in the percentage weight of the heads or shanks in terms of the HCW. However, RAC had an effect $(P=0.040)$ on the trotters, such that RAC-fed pigs had a smaller proportion of the side being trotters than those who did not receive RAC (Table 4). The tenderloins were weighed in pairs and, therefore, expressed in terms of whole carcass weight. The tenderloins from carcasses of RACfed pigs formed a greater $(P<0.001)$ proportion of the carcass than the tenderloins from non-RAC-fed pigs.

The supplementation of RAC increased the shoulder $(P=0.002)$, hindquarter $(P=0.026)$, loin $(P=$ $0.028)$, and belly $(P=0.044)$ percentages compared with the treatments that did not receive RAC (Table 5). There was no significant difference between the treatments for the bone and fat percentages of the shoulder; therefore, this increase should be in the muscle. This was confirmed by RAC treatments having greater $(P$ $<0.001)$ shoulder muscle percentages than those fed without RAC. Feeding RAC also increased the hindquarter muscle percentage $(P<0.001)$ while decreasing $(P=0.032)$ the hindquarter fat percentage. The 
Table 5. The effects of sex, ractopamine, and protein level on the shoulder, hindquarter, loin, and belly percentages and their proportions of muscle, fat, and bone (least squares means $\pm \mathrm{SEM}$ ) Continued on next page.

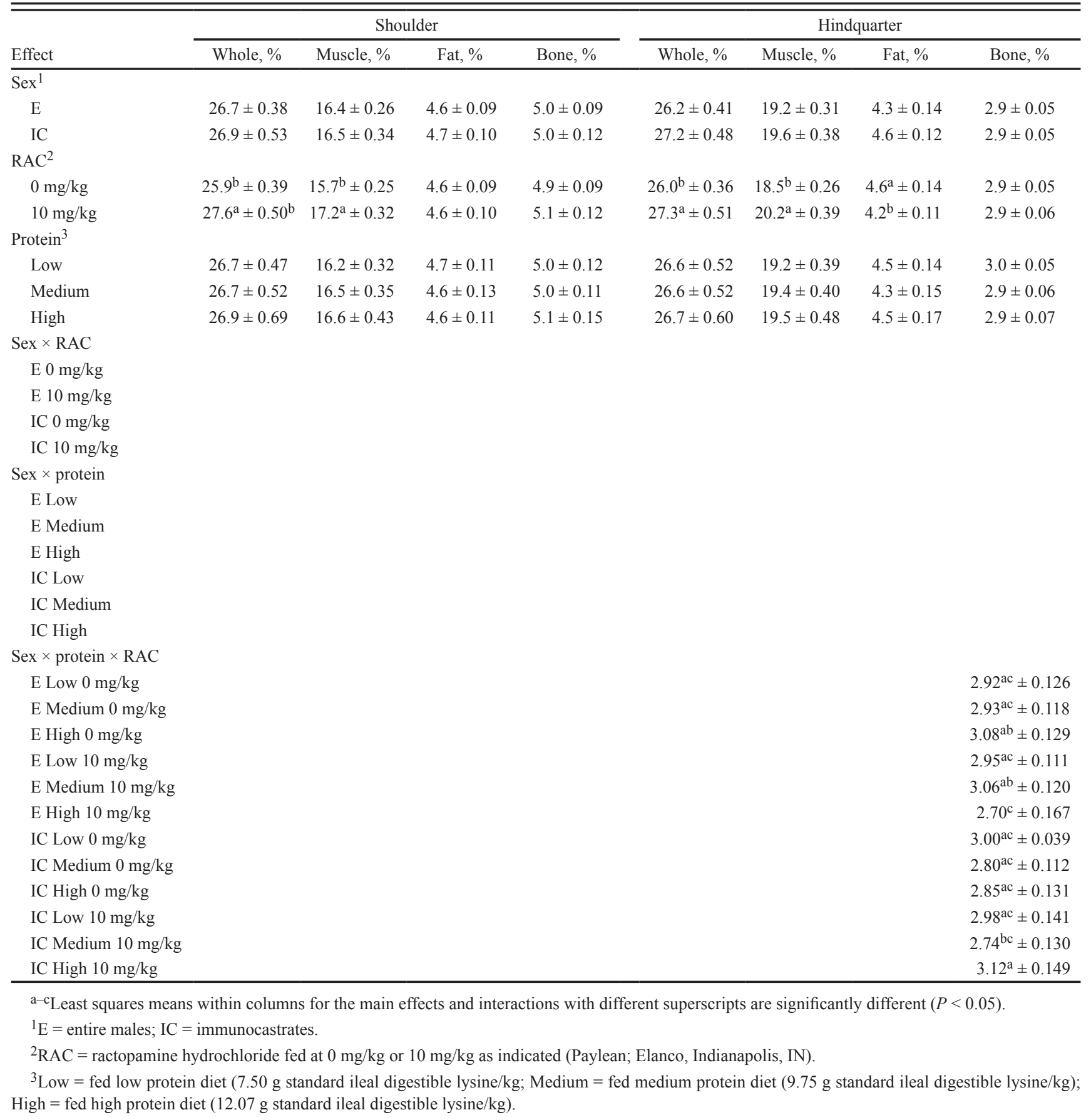

hindquarter bone percentage showed significant interaction between sex, RAC, and protein levels; however, the differences are small. Similar to the shoulder, RAC increased $(P=0.013)$ the loin muscle percentage whereas fat and bone percentages remained unaffected.

Immunocastration had a significant effect on the loin and the belly, by increasing the loin fat percentage $(P<0.001)$ and the whole belly cut percentage $(P$ $=0.006)$ as well as the belly fat percentage $(P<0.001)$. For the belly muscle, IC fed RAC had larger belly muscle percentages than $\mathrm{E}$ fed RAC $(P=0.005)$ and $\mathrm{E}$ who did not receive $\mathrm{RAC}(P=0.003)$ as well as IC who did not receive RAC $(P=0.009)$. There was also an interaction between sex and dietary protein for the bone percentage of the belly $(P=0.014)$ with $\mathrm{E}$ fed the low protein diet having smaller belly bone percentages than E fed the medium protein $\operatorname{diet}(P=0.003)$ and $\mathrm{E}$ fed the high protein $\operatorname{diet}(P=0.041)$ whereas $\mathrm{E}$ fed the medium protein diet had greater belly bone percentages than IC fed the medium protein $\operatorname{diet}(P=0.037)$ and IC fed the high protein diet $(P=0.006)$. Again, these differences were relatively small. 
Table 5. Continued.

\begin{tabular}{|c|c|c|c|c|c|c|c|c|}
\hline \multirow[b]{2}{*}{ Effect } & \multicolumn{4}{|c|}{ Loin } & \multicolumn{4}{|c|}{ Belly } \\
\hline & Whole, \% & Muscle, $\%$ & Fat, \% & Bone, $\%$ & Whole, \% & Muscle, $\%$ & Fat, $\%$ & Bone, $\%$ \\
\hline \multicolumn{9}{|l|}{$\overline{\operatorname{Sex}^{1}}$} \\
\hline $\mathrm{E}$ & $14.4 \pm 0.28$ & $8.3 \pm 0.20$ & $2.7^{\mathrm{b}} \pm 0.08$ & $3.0 \pm 0.10$ & $13.8^{\mathrm{b}} \pm 0.27$ & $10.5 \pm 0.22$ & $0.9^{\mathrm{b}} \pm 0.03$ & $2.3 \pm 0.04$ \\
\hline IC & $15.1 \pm 0.30$ & $8.5 \pm 0.20$ & $3.3^{\mathrm{a}} \pm 0.10$ & $2.9 \pm 0.07$ & $14.9^{\mathrm{a}} \pm 0.31$ & $11.4 \pm 0.26$ & $1.3^{\mathrm{a}} \pm 0.03$ & $2.2 \pm 0.04$ \\
\hline \multicolumn{9}{|l|}{$\mathrm{RAC}^{2}$} \\
\hline $0 \mathrm{mg} / \mathrm{kg}$ & $14.3^{b} \pm 0.23$ & $8.1^{\mathrm{b}} \pm 0.15$ & $3.0 \pm 0.08$ & $2.8 \pm 0.06$ & $14.0^{\mathrm{b}} \pm 0.25$ & $10.7 \pm 0.23$ & $1.0 \pm 0.03$ & $2.2 \pm 0.04$ \\
\hline $10 \mathrm{mg} / \mathrm{kg}$ & $15.2^{\mathrm{a}} \pm 0.34$ & $8.8^{\mathrm{a}} \pm 0.23$ & $3.0 \pm 0.11$ & $3.1 \pm 0.11$ & $14.8^{\mathrm{a}} \pm 0.33$ & $11.2 \pm 0.26$ & $1.0 \pm 0.03$ & $2.3 \pm 0.04$ \\
\hline \multicolumn{9}{|l|}{ Protein $^{3}$} \\
\hline Low & $14.8 \pm 0.38$ & $8.4 \pm 0.23$ & $3.1 \pm 0.13$ & $2.9 \pm 0.08$ & $14.2 \pm 0.41$ & $10.9 \pm 0.35$ & $1.0 \pm 0.03$ & $2.2 \pm 0.05$ \\
\hline Medium & $14.7 \pm 0.31$ & $8.4 \pm 0.20$ & $3.0 \pm 0.12$ & $2.9 \pm 0.08$ & $14.5 \pm 0.35$ & $11.0 \pm 0.31$ & $1.1 \pm 0.04$ & $2.3 \pm 0.06$ \\
\hline High & $14.8 \pm 0.39$ & $8.5 \pm 0.31$ & $3.0 \pm 0.12$ & $3.0 \pm 0.15$ & $14.4 \pm 0.34$ & $10.9 \pm 0.25$ & $1.0 \pm 0.04$ & $2.2 \pm 0.05$ \\
\hline \multicolumn{9}{|l|}{ Sex $\times$ RAC } \\
\hline E $0 \mathrm{mg} / \mathrm{kg}$ & & & & & & $10.6^{\mathrm{b}} \pm 0.36$ & & \\
\hline E $10 \mathrm{mg} / \mathrm{kg}$ & & & & & & $10.3^{b} \pm 0.27$ & & \\
\hline IC 0 mg/kg & & & & & & $10.8^{\mathrm{b}} \pm 0.31$ & & \\
\hline IC $10 \mathrm{mg} / \mathrm{kg}$ & & & & & & $12.1^{\mathrm{a}} \pm 0.39$ & & \\
\hline \multicolumn{9}{|l|}{ Sex $\times$ protein } \\
\hline E Low & & & & & & & & $2.1^{\mathrm{c}} \pm 0.06$ \\
\hline E Medium & & & & & & & & $2.4^{\mathrm{a}} \pm 0.06$ \\
\hline E High & & & & & & & & $2.3^{\mathrm{ab}} \pm 0.07$ \\
\hline IC Low & & & & & & & & $2.3^{\mathrm{ac}} \pm 0.07$ \\
\hline IC Medium & & & & & & & & $2.2^{\mathrm{cb}} \pm 0.09$ \\
\hline IC High & & & & & & & & $2.1^{\mathrm{cb}} \pm 0.06$ \\
\hline \multicolumn{9}{|l|}{ Sex $\times$ protein $\times$ RAC } \\
\hline \multicolumn{9}{|l|}{ E Low $0 \mathrm{mg} / \mathrm{kg}$} \\
\hline \multicolumn{9}{|l|}{ E Medium $0 \mathrm{mg} / \mathrm{kg}$} \\
\hline \multicolumn{9}{|l|}{ E High 0 mg/kg } \\
\hline \multicolumn{9}{|l|}{ E Low 10 mg/kg } \\
\hline \multicolumn{9}{|l|}{ E Medium $10 \mathrm{mg} / \mathrm{kg}$} \\
\hline \multicolumn{9}{|l|}{ E High 10 mg/kg } \\
\hline \multicolumn{9}{|l|}{ IC Low 0 mg/kg } \\
\hline \multicolumn{9}{|l|}{ IC Medium $0 \mathrm{mg} / \mathrm{kg}$} \\
\hline \multicolumn{9}{|l|}{ IC High 0 mg/kg } \\
\hline \multicolumn{9}{|l|}{ IC Low 10 mg/kg } \\
\hline \multicolumn{9}{|l|}{ IC Medium $10 \mathrm{mg} / \mathrm{kg}$} \\
\hline IC High 10 mg/kg & & & & & & & & \\
\hline
\end{tabular}

\section{DISCUSSION}

\section{Live Weight, HCW, Carcass Scores, and Fat Thickness}

Immunocastration increased the live weight at slaughter by approximately $5 \mathrm{~kg}$ compared with E; however, no differences were seen in dressed HCW. This is most likely due to an increase in feed intake and, therefore, gut fill as well as factors such as bladder fill and organ weight. This is supported by Boler et al. (2014), who showed that IC had greater full intestinal tract and empty digestive tract percentages as well as greater gut fill percentages than $\mathrm{E}$ when expressed as a percentage of their final live weight. Boler et al. (2014) further showed that the male reproductive tract (testes, penis, prepuce, and residual components) contribute a smaller proportion of the live weight in IC than in $\mathrm{E}$ and that slight differences in visceral organ weights also contribute to the differences seen in between IC and $\mathrm{E}$ in dressing percentage. The absence of male steroid hormones allows the liver to function more efficiently with regards to the metabolism of compounds such as skatole (Babol et al., 1999), thus effecting liver activity, which could influence the liver weight; however, the effect of immunocastration on liver functioning is unclear. Although Boler et al. (2014) found no differences between IC and $\mathrm{E}$ in liver percentage of live weight, both IC and E had greater liver percentages than surgical castrates. This could support the statement that the liver of surgical castrates functions more efficiently; however, the lack of differences be- 


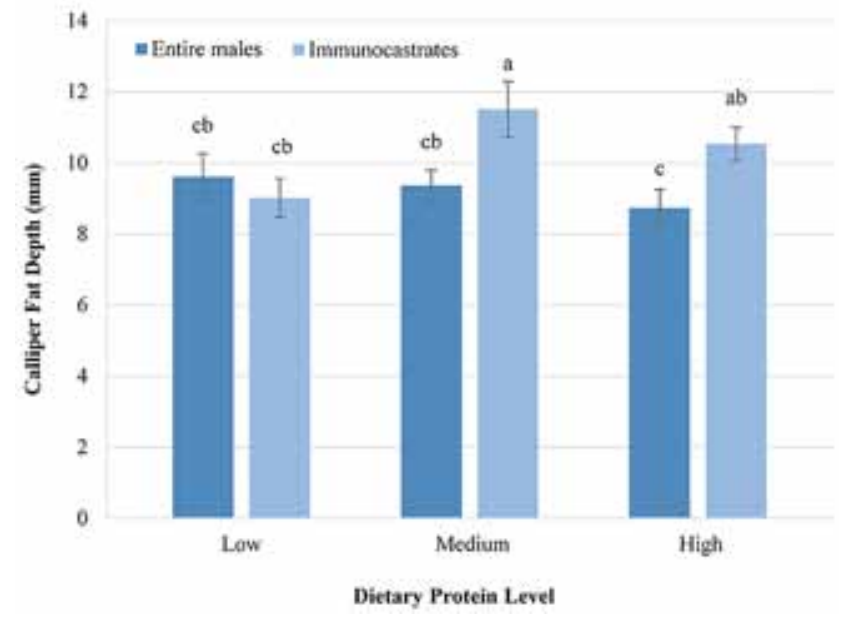

Figure 1. Interaction between sex and protein level for the mean caliper backfat depth $(\mathrm{mm})$ of the longissimus thoracis for entire males and immunocastrates fed at low, medium, and high dietary protein. ${ }^{\mathrm{a}-\mathrm{c}}$ The different alphabetical letters denote significant differences $(P<0.05)$ between the mean values. Vertical bars indicate SEM.

tween IC and surgical castrates could be due to the fact that the effect of male steroid hormones on the livers of surgical castrates has been absent for a longer period.

Numerous factors including the amount of time between the second vaccination and slaughter and whether or not weights were distributed evenly across treatment groups may influence the live weight and $\mathrm{HCW}$. Therefore, the conclusion varies between studies as to whether live weight and HCW differ between sexes (Fàbrega et al., 2010; Gispert et al., 2010; Weiler et al., 2013) or not (Bonneau et al., 1994; Zamaratskaia et al., 2008; Lealiifano et al., 2011). Backfat thickness is also influenced by various factors such as diet, the physiological age at which the booster vaccination is given, and its timing relative to slaughter and, therefore, conclusions also vary. The current study indicated no difference in HGP backfat thickness between the 2 sexes, which is in agreement with Dunshea et al. (2001) and Lealiifano et al. (2011), who both allowed for $4 \mathrm{wk}$ between the booster and slaughter, as done in the current trial. Lowe et al. (2014a) evaluated the carcass cutability of IC fed RAC and found that there were no differences in loin fat depth between IC fed RAC and IC fed without RAC when the Fat-OMeater (SFK Technology, Herley, Denmark) was used. Although the control sex used was surgical castrates, it is important to include this work as the pigs were slaughtered at live weights similar to the current trial compared with those who were slaughtered at lighter weights by Rikard-Bell et al. (2009). However, the diet used by Lowe et al. (2014a) had a lower CP content $(174 \mathrm{~g} / \mathrm{kg})$ and RAC level $(5 \mathrm{mg} / \mathrm{kg})$ than those used in this study. This could partially explain the greater backfat depths $(23.93 \pm 0.35 \mathrm{~mm}$ for RAC-fed C) seen by Lowe et al. (2014a) in comparison to those seen in the current study.

Results from backfat measurements may vary between instruments used as well as between users; for instance, should the carcass be particularly long or the user is short in comparison, the HGP may not be inserted perpendicularly to the carcass. It was for this reason that the caliper fat thickness of the loins was measured at $48 \mathrm{~h}$ postmortem. From the significant interaction for sex and protein levels on the caliper backfat depths, one could say that the level of protein affected the backfat thickness and the response of which depended on the sex of the pig. This is evident at the high protein level, where E had a significantly decreased caliper backfat depth compared with IC, which are likely oversupplied with protein at this point. This difference in response to dietary protein level indicates a loss in anabolic potential and, therefore, likely a decrease in the protein requirements of IC. Seeing as there were no differences between the dietary protein levels for $\mathrm{E}$ and that IC fed the low protein diet was not different from IC fed the high protein diet with regards to caliper backfat depth, feeding the low-protein diet would also result in the least carcass backfat depth and, therefore, the best classification should the HCW not differ as with the current study. The backfat thickness could be further reduced by the inclusion of RAC with the lowprotein diet, which appears to be sufficient should the focus be placed on backfat depth. However, the dietary protein level is usually decided on based on the resultant growth performance and, therefore, factors such as ADG and feed efficiency are of importance.

Feeding RAC influenced the live weight at slaughter and caliper backfat thickness without affecting the HCW or HGP backfat thickness. Including RAC in the diets increased final BW by approximately $4 \mathrm{~kg}$ and decreased caliper backfat thickness by approximately 1 $\mathrm{mm}$. Lowe et al. (2014b) concluded that feeding RAC at $5 \mathrm{mg} / \mathrm{kg}$ to IC increased the live weight at slaughter, with no effect on the dressing percentage. Conclusions with regards to the effects of $10 \mathrm{mg} / \mathrm{kg}$ on carcass traits vary as the duration of inclusion, dietary protein levels, and genotype of the pig could influence the response. However, the current study agrees with Carr et al. (2005b), who also fed $10 \mathrm{mg} / \mathrm{kg}$ RAC for $28 \mathrm{~d}$ to PIC pigs and found a significant difference for final BW between 0 and $10 \mathrm{mg} / \mathrm{kg}$ treatments but no difference in dressed HCW. It can also be seen by their results that whether the differences in backfat thickness were significant or not depended on the site measured, such that there was a significant difference between treatments for 10th and last rib measurements and no differences for the first rib and last lumbar measurements. In contrast, a meta-analysis of 29 publications from 1990 
to 2007 by Andretta et al. (2012) showed that feeding RAC increased HCW and an earlier meta-analysis by Apple et al. (2007) showed that feeding $10 \mathrm{mg} / \mathrm{kg}$ RAC increased HCW by $3.1 \%$. These contradictory results were highlighted by Apple et al. (2007) regarding the effect of feeding $10 \mathrm{mg} / \mathrm{kg} \mathrm{RAC}$ on $\mathrm{HCW}$, with some researchers finding a significant increase (Stites et al., 1991; Herr et al., 2001; Marchant-Forde et al., 2003; Armstrong et al., 2004; Carr et al., 2005a; See et al., 2005), those who found no effect (Watkins et al., 1990; Crome et al., 1996; Stoller et al., 2003; Carr et al., 2005b), and those who found a negative effect (Aalhus et al., 1990; Stoller et al., 2003). The data regarding feeding RAC to IC is currently very limited; however, Rikard-Bell et al. (2009) found that HCW was increased by feeding RAC to IC and that HCW were greater for IC than both boars and gilts. Although this agrees with Apple et al. (2007) and Andretta et al. (2012) that feeding RAC can increase the HCW, it cannot be compared with the current study because a step-up in inclusion level of RAC $(5 \mathrm{mg} / \mathrm{kg}$ for $14 \mathrm{~d}$ followed by $10 \mathrm{mg} / \mathrm{kg}$ for $17 \mathrm{~d}$ ) was used by RikardBell et al. (2009).

Backfat thickness is inversely correlated to the duration of RAC supply and level of inclusion as well as the estimated RAC intake (Andretta et al., 2012) and, therefore, it is expected for results to vary between those who found differences in backfat thickness (Watkins et al., 1990; Marchant-Forde et al., 2003; Apple et al., 2004b; Carr et al., 2005b;) and those who did not (Aalhus et al., 1990; Stites et al., 1991; Crome et al., 1996; Herr et al., 2001; Stoller et al., 2003; Carr et al., 2005a; See et al., 2005; Hinson et al., 2011). In light of these findings, the theory that RAC repartitions nutrients away from lipid synthesis to protein accretion does not always appear to hold true. Apple et al. (2007) showed that there is a numerical decrease in backfat thickness when RAC is fed but this is not always statistically significant, which is true for the current study's HGP backfat depth data. The caliper backfat measurements and linear carcass results of this study agree to a certain extent with Webster et al. (2007), who found that increased dietary lysine decreased the average backfat thickness but not the carcass characteristics of pigs when fed $10 \mathrm{mg} / \mathrm{kg}$ RAC, except that in the current research, sex affected the response to protein levels. Lysine levels have also been shown to increase live slaughter weight and HCW of IC (Boler et al., 2011); however, no effect was seen in the current results for protein levels. This could be due to the fact that Boler et al. (2011) increased only the dietary lysine levels and followed a step-down lysine program from grower to first vaccination and then from first vaccination to the booster. This was not done in the current trial where all pigs received the same lysine level up until the booster when they were changed to the various increased lysine levels with all AA ratios maintained. Therefore, even at the low protein level, all other AA were balanced and not limiting in the current trial, which could have otherwise affected lipid versus protein deposition.

When the current HGP fat thickness and caliper fat thickness results are considered, a large variation in measurements for the 2 instruments is seen. The average fat thickness across the various main effects was $17 \mathrm{~mm}$ for the HGP and between 8.7 and $11.5 \mathrm{~mm}$ for the caliper measurements; therefore, a difference of approximately 6 to $9 \mathrm{~mm}$ exists. The HGP includes the skin thickness in its measurements; however, caliper skin thickness was approximately $3.8 \mathrm{~mm}$, which leaves 3 to $6 \mathrm{~mm}$ unaccounted for. Some of this difference seen between instruments could be attributed to shrinkage of the adipose tissue as the caliper measurements were taken on the cold loin cut. This reiterates the effect of measurement techniques on the results for backfat thickness and factors such as the perpendicular insertion of the HGP need to be taken into account. Boler et al. (2011) compared the use of the Fat-OMeater, dissection, and chemical analysis to estimate the lean content of entire, surgical castrated, and immunocastrated pig carcasses. They found that the Fat$\mathrm{O}-$ Meater detected fewer differences in estimated lean amongst sex treatments and those differences detected where smaller in comparison. This supports the questioning of the lack of accuracy of an optical probe to detect and estimate differences in lean.

Lealiifano et al. (2011) found that $\mathrm{E}$ had a greater carcass lesion score than IC when their animals were group housed and thus allowed to interact with each other. The current carcass lesion score data collected at the abattoir could not conclude anything about fighting in lairage most probably due to the shorter period in lairage and, therefore, it was not possible to identify if IC were bullied by E. Therefore, in future, the pigs should be kept longer in lairage to ascertain the effect on fighting and carcass lesions.

\section{Carcass Cutting Yields}

Due to the fact that the way in which the carcass has been sectioned varies between studies, carcass cutting yield data differs, which may limit the ability to compare them. Very few studies have trimmed the whole cuts into muscle, fat, and bone as has been done in the current study and, therefore, this data is unique from a practical perspective as it determines the value of the carcass with a greater value been placed on muscle (for example the loin muscle used in the mak- 
ing of back bacon) than on fat (and skin) as the latter is typically used in the production of cheaper emulsions.

Lowe et al. (2014a) found that IC fed RAC had less fat and greater carcass cutting yields than the surgically castrated controls, with no difference on pork quality. Although a lower RAC inclusion level and different control sex was used, limited data is currently available on carcass cutting yields of IC fed RAC. When the effect of RAC on the cutting yields of IC is evaluated, feeding RAC has little effect on the whole shoulder, loin, ham, and belly when expressed as a percentage of the HCW (Lowe et al., 2014a). The only whole cut percentage influenced by immunocastration in the current study was the belly. In terms of the composition of the cuts, immunocastration increased the loin fat percentage and the belly fat percentage. Although this is in agreement with Gispert et al. (2010), who found a greater proportion of subcutaneous loin fat in IC, Gispert et al. (2010) did not control time of slaughter after the second injection as done within the current study. The lack of effect of immunocastration on the head, trotters, shoulder, hindquarter, and loin percentages is supported by Bonneau et al. (1994) as well as Gispert et al. (2010), except for the whole loin percentage, where Gispert et al. (2010) found that immunocastration increased loin percentage, which was not observed in the current research. The current results further agree and disagree with Gispert et al. (2010) in various ways. They agree with regards to the fact that immunocastration increased the proportion of the carcass represented by the belly cut and did not influence tenderloin (tenderloin) percentage. However, they disagree with the conclusion that IC had more muscle, more subcutaneous fat, and less bone in the ham than $\mathrm{E}$ in terms of percentage of the carcass and that IC had lighter heads than E in the study conducted by Gispert et al. (2010). The ham cut was used by Gispert et al. (2010) and, therefore, the trotter and shank were included in this measurement, but in the current study, the trotters and shanks were evaluated separately, which could influence the findings. Both the current results and Gispert et al. (2010) do not agree with Bonneau et al. (1994), who found no difference in the belly cut between E and IC in terms of the carcass percentage. This further illustrates the differences in conclusions regarding carcass yields when different sectioning techniques and cuts are used for evaluation.

Interactions existed between sex and protein for the belly bone percentage as well as between sex, RAC, and protein for the hindquarter bone percentage. The effect of sex, RAC, and lysine on bone can be seen in research by Moore et al. (2009) and Boler et al. (2011). Moore et al. (2009) found that immunocastration and RAC decreased the percentage of bone when the side of the carcass was analyzed using dual energy X-ray absorptiometry. Boler et al. (2011) found bone weight to be heavier in E than in IC and surgical castrates, with the exception of IC fed $9 \mathrm{~g}$ lysine $/ \mathrm{kg}$. Most of the differences for the hindquarter bone in the current results between the treatments appear to be biologically negligible except for pigs fed RAC at medium lysine and high lysine. For example, the highest hindquarter bone percentage was $3.12 \pm 0.15 \%$ for IC fed RAC and the high protein diet and the lowest was $2.70 \pm 0.17 \%$ for E fed RAC and the high protein diet. This may become important in cuts intended for cured meat production, such as the hindquarter, where the price of the cut is determined by the bone:meat ratio. The fact that there was no effect of protein on any of the whole cuts, muscle or fat percentage in the current study agrees with Boler et al. (2011), who did not find differences in whole ham percentages from IC, E, and surgical castrates regardless of lysine percentage fed.

Including $10 \mathrm{mg} / \mathrm{kg}$ RAC increased the percentage of the HCW represented by the shoulder, hindquarter, loin, and belly as well as the shoulder muscle, hindquarter muscle, and loin muscle while decreasing the hindquarter fat percentage. Therefore, the increase in cut percentages seems to be largely due to increased lean muscle growth rather than decreased fat deposition, with the exception of the hindquarter. A decreased fat percentage in the hindquarter may also negatively affect the desirability of the cut for dried cured meat production and, therefore, the value if it is sold for this particular purpose. Although those pigs fed RAC had greater tenderloin percentages and smaller trotter and shank percentages, the statistical differences are negligible from an industry point of view because the trotters have a low resale value and the tenderloins make up such a small proportion of the carcass. The increase in loin percentage agrees with Rikard-Bell et al. (2009) and the influence of RAC on the muscle and fat of the shoulder agrees with Moore et al. (2009), who found that RAC increased lean tissue weights but did not alter fat tissue weights of the half carcass. However, they differ from Carr et al. (2005a), who found no difference in the loin, shoulder, and belly as a percentage of the carcass when RAC was fed but did find differences in their respective weights. This could be due to the fact that Carr et al. (2005a) fed RAC until the pigs reached slaughter weight rather than for a specified period and, therefore, the supplementation period varied from 25 to $41 \mathrm{~d}$. It has been noted that the effect of RAC decreases as the duration of supply increases, as the $\beta$-adrenoceptors are downregulated within the fat tissue and/or desensitized in skeletal muscle tissue (Spurlock et al., 1994). Although the inclusion of RAC 
does not affect the total number of muscle fibers, the diameters of the white muscle fibers increase in response to RAC supplementation (Aalhus et al., 1992). Therefore, the increase in the proportion of the HCW represented by the muscle tissue of the various cuts is likely due to the effect of RAC on the muscle fiber diameters.

\section{Conclusion}

Immunocastration and RAC inclusion resulted in heavier live BW at slaughter but not $\mathrm{HCW}$. An interaction for sex and protein levels for the caliper backfat depths indicates that the protein requirements could differ between the sexes because an oversupply or undersupply of balanced protein can result in increased fat deposition. It could prove beneficial to further evaluate the effect of protein levels on IC using a wider protein level range as many carcass classification systems, and, therefore, the price of the carcass, rely on the backfat thickness as well as HCW. Seeing as no differences were seen in the HGP backfat thickness, immunocastration did not influence the PORCUS carcass classification. In light of the differences seen in measurements between the HGP and the caliper, it could be preferred to make use of the caliper method to establish backfat thickness due to various issues such as handling error and correct calibration with regards to the HGP used in a commercial system.

Including $10 \mathrm{mg} / \mathrm{kg}$ RAC decreased caliper backfat thickness and increased the carcass cutting yields as well as the lean yields of these cuts, thus increasing the value of the carcasses. Immunocastration increased the percentage of the half carcass weight represented by the belly cut, loin fat, and belly fat whereas the significant interaction between sex and RAC for belly muscle indicted that by including RAC at $10 \mathrm{mg} / \mathrm{kg}$ in the diet of IC, belly muscle percentage increased by approximately $2 \%$ of the half carcass weight. Further research should also be done in terms of the bone percentage of the ham weight because the bone:muscle ratio is an important factor in the cost of cured ham products. Therefore, one can conclude that RAC increased the muscle percentages of all the cuts in terms of the HWC but decreased only the fat percentage of the hindquarter, when expressed as a proportion of the HCW. The current results indicate that the carcass traits of IC are close to those of $\mathrm{E}$ but the negative effects on backfat thickness and lean meat yield due to immunocastration could be avoided should the correct dietary protein level be provided and that including RAC in the diet provided improved carcass cutting yields and lean yields of the shoulder, hindquarter, and loin.

\section{LITERATURE CITED}

Aalhus, J. L., S. D. M. Jones, A. L. Schaefer, A. K. W. Tong, W. M. Robertson, J. K. Merrill, and A. C. Murray. 1990. The effect of ractopamine on performance, carcass composition and meat quality of finishing pigs. Can. J. Anim. Sci. 70:943-952. doi:10.4141/cjas90-113

Aalhus, J. L, A. L. Schaefer, A. C. Murray, and S. D. M. Jones. 1992. The effect of ractopamine on myofibre distribution and morphology and their relation to meat quality in swine. Meat Sci. 31:397-409.

Andretta, I., M. Kipper, C. R. Lehnen, A. B. Demori, A. Remus, and P. A. Lovatto. 2012. Meta-analysis of the relationship between ractopamine and dietary lysine levels on carcass characteristics in pigs. Livest. Sci. 143:91-96. doi:10.1016/j. livsci.2011.09.004

Apple, J., C. Maxwell, D. Brown, K. Friesen, R. Musser, Z. Johnson, and T. Armstrong. 2004a. Effects of dietary lysine and energy density on performance and carcass characteristics of finishing pigs fed ractopamine. J. Anim. Sci. 82:3277-3287.

Apple, J., C. Maxwell, D. Brown, K. Friesen, R. Musser, Z. Johnson, and T. Armstrong. 2004b. Effects of ractopamine and dietary fat source on performance and carcass characteristics of growing-finishing swine. J. Anim. Sci. 82(Suppl. 1):135.

Apple, J., P. Rincker, F. McKeith, S. Carr, T. Armstrong, and P. Matzat. 2007. Review: Meta-analysis of the ractopamine response in finishing swine. Prof. Anim. Sci. 23:179-196.

Armstrong, T., D. Ivers, J. Wagner, D. Anderson, W. Weldon, and E. Berg. 2004. The effect of dietary ractopamine concentration and duration of feeding on growth performance, carcass characteristics, and meat quality of finishing pigs. J. Anim. Sci. 82:3245-3253.

Babol, J., E. J. Squires, and K. Lundström. 1999. Relationship between metabolism of androstenone and skatole in intact male pigs. J. Anim. Sci. 77:84-92.

Boler, D., L. Kutzler, D. Meeuwse, V. King, D. Campion, F. McKeith, and J. Killefer. 2011. Effects of increasing lysine on carcass composition and cutting yields of immunologically castrated male pigs. J. Anim. Sci. 89:2189-2199. doi:10.2527/ jas.2010-3640

Boler, D., C. L. Puls, D. L. Clark, M. Ellis, A. L. Schroeder, P. D. Matzat, J. Killefer, F. K. McKeith, and A. C. Dilger. 2014. Effects of immunological castration (Improvest) on changes in dressing percentage and carcass characteristics of finishing pigs. J. Anim. Sci. 92:359-368. doi:10.2527/jas.2013-6863

Bonneau, M., R. Dufour, C. Chouvet, C. Roulet, W. Meadus, and E. Squires. 1994. The effects of immunization against luteinizing hormone-releasing hormone on performance, sexual development, and levels of boar taint-related compounds in intact male pigs. J. Anim. Sci. 72:14-20.

Carr, S., D. J. Ivers, D. B. Anderson, D. J. Jones, D. H. Mowrey, M. B. England, J. Killefer, P. J. Rincker, and F. McKeith. 2005a. The effects of ractopamine hydrochloride on lean carcass yields and pork quality characteristics. J. Anim. Sci. 83:2886-2893.

Carr, S., P. Rincker, J. Killefer, D. Baker, M. Ellis, and F. McKeith. 2005b. Effects of different cereal grains and ractopamine hydrochloride on performance, carcass characteristics, and fat quality in late-finishing pigs. J. Anim. Sci. 83:223-230.

Crome, P. K., F. K. McKeith, T. R. Carr, D. J. Jones, D. H. Mowrey, and J. E. Cannon. 1996. Effect of ractopamine on growth performance, carcass composition, and cutting yields of pigs slaughtered at 107 and 125 kilograms. J. Anim. Sci. 74:709-716. 
Dunshea, F., C. Colantoni, K. Howard, I. McCauley, P. Jackson, K. Long, S. Lopaticki, E. Nugent, J. Simons, J. Walker, and D. P. Hennessey. 2001. Vaccination of boars with a GnRH vaccine (Improvac) eliminates boar taint and increases growth performance. J. Anim. Sci. 79:2524-2535.

Fàbrega, E., A. Velarde, J. Cros, M. Gispert, P. Suárez, J. Tibau, and J. Soler. 2010. Effect of vaccination against gonadotrophin-releasing hormone, using Improvac ${ }^{\mathrm{TM}}$, on growth performance, body composition, behaviour and acute phase proteins. Livest. Sci. 132:53-59. doi:10.1016/j.livsci.2010.04.021

Gispert, M., M. Oliver, A. Velarde, P. Suarez, J. Pérez, and M. Font i Furnols. 2010. Carcass and meat quality characteristics of immunocastrated male, surgically castrated male, entire male and female pigs. Meat Sci. 85:664-670. doi:10.1016/j.meatsci.2010.03.021

Government Gazette. 1992. Regulation No. R. 1748. Agricultural Product Standards Act 119 of 1990: Regulations regarding the classification and marking of meat intended for sale in the Republic of South Africa. http:/www.greengazette.co.za/ notices/agricultural-product-standards-act-119-1990-regulations-regarding-the-classification-and-marking-of-meatintended-for-sale-in-the-republic-of-south-africa_20150130GGR-38431-00055.pdf. (Accessed 10 August 2014.)

Herr, C. T., S. L. Hankins, A. P. Schinckel, and B. T. Rickert. 2001. Evaluation of three genetic populations of pigs for response to increasing levels of ractopamine. J. Anim. Sci. 79(Suppl. 2):73.

Hinson, R., B. Wiegand, M. Ritter, G. Allee, and S. Carr. 2011. Impact of dietary energy level and ractopamine on growth performance, carcass characteristics, and meat quality of finishing pigs. J. Anim. Sci. 89:3572-3579. doi:10.2527/jas.2010-3302

Hoffman, L. C. 1987. Die doeltreffendheid van sekere parameters ter bepaling van die weefselsamestelling van varkkarkasse. (In Afrikaans.) MSc thesis, University of Stellenbosch, Western Cape, South Africa.

Lealiifano, A., J. R. Pluske, R. Nicholls, F. Dunshea, R. Campbell, D. Hennessy, D. Miller, C. F. Hansen, and B. Mullan. 2011. Reducing the length of time between slaughter and the secondary gonadotropin-releasing factor immunization improves growth performance and clears boar taint compounds in male finishing pigs. J. Anim. Sci. 89:2782-2792. doi:10.2527/jas.2010-3267

Lowe, B. K., G. D. Gerlemann, S. N. Carr, P. J. Rincker, A. L. Schroeder, D. B. Petry, F. K. McKeith, G. L. Allee, and A. C. Dilger. 2014a. Effects of feeding ractopamine hydrochloride (Paylean) to physical and immunological castrates (Improvest) in a commercial setting on carcass cutting yields and loin quality. J. Anim. Sci. 92:3715-3726. doi:10.2527/jas.2013-7515

Lowe, B. K., G. D. Gerlemann, S. N. Carr, P. J. Rincker, A. L. Schroeder, D. B. Petry, F. K. McKeith, G. L. Allee, and A. C. Dilger. 2014b. Effects of feeding ractopamine hydrochloride (Paylean) to physical and immunological castrates (Improvest) in a commercial setting on growth performance and carcass characteristics. J. Anim. Sci. 92:3727-3735. doi:10.2527/jas.2013-7516

Marchant-Forde, J. N., D. C. Lay Jr., E. A. Pajor, B. T. Richert, and A. P. Schinckel. 2003. The effects of ractopamine on the behavior and physiology of finishing pigs. J. Anim. Sci. 81:416-422.

McCauley, I., G. M. Cronin, D. P. Hennessy, R. J. Smits, and F. R. Dunshea. 2001. Carcass damage at slaughter is reduced equally by surgical and immunological castration. In: P. D. Cranwell, editor, Manipulating pig production VIII. Australasian Pig Science Association, Adelaide, SA, Australia. p. 82.
Moore, K., F. Dunshea, B. Mullan, D. Hennessy, and D. D'Souza. 2009. Ractopamine supplementation increases lean deposition in entire and immunocastrated male pigs. Anim. Prod. Sci. 49:1113-1119. doi:10.1071/AN09076

Needham, T., and L. C. Hoffman. 2015. Physical meat quality and chemical composition of the Longisimuss thoracis of entire and immunocastrated pigs fed varying dietary protein levels with and without ractopamine hydrochloride. Meat Sci. 110:101-108.

Pieterse, E. 2006. Effects of increased slaughter weight of pigs on pork production. PhD Diss., University of Stellenbosch, Western Cape, South Africa.

Pig Improvement Company (PIC). 2011. Nutrients specification manual. http://piclatam.com/Agroinformacion/MANUAL.pdf. (Accessed 17 April 2014.)

Rikard-Bell, C., M. Curtis, R. J. Van Barneveld, B. Mullan, A. C. Edwards, N. Gannon, D. J. Henman, P. E. Hughes, and F. Dunshea. 2009. Ractopamine hydrochloride improves growth performance and carcass composition in immunocastrated boars, intact boars, and gilts. J. Anim. Sci. 87:3536-3543. doi: $10.2527 /$ jas.2009-2002

SANS. 2008. SANS 10386. The South African National Standard for the Care and Use of Animals for Scientific Purposes.http:// sun025.sun.ac.za/portal/page/portal/Staff_Personeel/Portal Home/Research/Research Ethics/SANS1030̄86.pdf. (Accessed 17 April 2013.)

See, M. T., T. A. Armstrong, P. D. Matzat, B. A. Belstra, F. K. McKeith, P. J. Rincker, L. Xi, J. Odle, M. Culbertson, W. Herring, and J. Hansen. 2005. Effect of ractopamine feeding level on growth performance and carcass composition. J. Anim. Sci. 83(Suppl. 2):27.

Spurlock, M., J. Cusumano, S. Ji, D. Anderson, C. Smith, D. Hancock, and S. Mills. 1994. The effect of ractopamine on beta-adrenoceptor density and affinity in porcine adipose and skeletal muscle tissue. J. Anim. Sci. 72:75-80.

Stites, C. R., F. K. McKeith, S. D. Singh, P. J. Bechtel, D. H. Mowrey, and D. J. Jones. 1991. The effect of ractopamine hydrochloride on the carcass cutting yields of finishing swine. J. Anim. Sci. 69:3094-3101.

Stoller, G. M., H. N. Zerby, S. J. Moeller, T. J. Baas, C. Johnson, and L. E. Watkins. 2003. The effect of feeding ractopamine (Paylean) on muscle quality and sensory characteristics in three diverse genetic lines of swine. J. Anim. Sci. 81:1508-1516.

Watkins, L. E., D. J. Jones, D. H. Mowrey, D. B. Anderson, and E. L. Veenhuizen. 1990. The effect of various levels of ractopamine hydrochloride on the performance and carcass characteristics of finishing swine. J. Anim. Sci. 68:3588-3595.

Webster, M. J., R. Goodband, M. Tokach, J. Nelssen, S. Dritz, J. Unruh, K. Brown, D. Real, J. Derouchey, J. Woodworth, C. N. Groesbeek, and T. A. Marsteller. 2007. Interactive effects between ractopamine hydrochloride and dietary lysine on finishing pig growth performance, carcass characteristics, pork quality, and tissue accretion. Prof. Anim. Sci. 23:597-611.

Weiler, U., M. Götz, A. Schmidt, M. Otto, and S. Müller. 2013. Influence of sex and immunocastration on feed intake behavior, skatole and indole concentrations in adipose tissue of pigs. Animal 7:300-308. doi:10.1017/S175173111200167X

Zamaratskaia, G., L. Rydhmer, H. K. Andersson, G. Chen, S. Lowagie, K. Andersson, and K. Lundström. 2008. Long-term effect of vaccination against gonadotropin-releasing hormone, using Improvac ${ }^{\mathrm{TM}}$, on hormonal profile and behaviour of male pigs. Anim. Reprod. Sci. 108:37-48. doi:10.1016/j.anireprosci.2007.07.001 
Reproduced with permission of the copyright owner. Further reproduction prohibited without permission. 